\title{
PERILAKU PENCEGAHAN ANAK DI BESUKI RAYA DALAM MENANGGAPI ANCAMAN YANG DIRASAKAN DARI PANDEMI COVID-19
}

\author{
Eka Afdi Septiyono, Iis Rahmawati, Sukma Ningrum \\ Fakultas Keperawatan Universitas Jember \\ Email: eka.psik@unej.ac.id
}

\begin{abstract}
Abstrak
COVID-19 adalah penyakit menular yang menyerang sistem pernapasan yang disebabkan oleh infeksi virus corona. Virus ini dapat menyebabkan gangguan ringan pada sistem pernapasan, infeksi paru-paru berat, hingga kematian. COVID-19 dapat menyerang siapa saja, terutama anak-anak. Penelitian ini bertujuan untuk menggali pengalaman anak-anak dalam pencegahan COVID-19. Penelitian ini menggunakan metode kualitatif untuk menggali pengalaman anak. Partisipan dalam penelitian ini adalah sepuluh anak yang dipilih melalui teknik purposive sampling. Hasil yang diperoleh ada lima tema yaitu Perceived Severity, Perceived susceptibility, Perceived Benefit, Perceived Bariers, dan Health Motivation. Dalam penelitian ini, perilaku preventif yang dilakukan oleh anak adalah menjaga jarak, memakai masker, mencuci tangan, dan mengkonsumsi vitamin dan makanan bergizi. Diharapkan perawat dapat memotivasi agar anak dapat melakukan perilaku preventif agar tidak tertular COVID-19.
\end{abstract}

Kata kunci: COVID-19, preventif, qnak

\begin{abstract}
COVID-19 is an infectious disease that attacks the respiratory system caused by infection with the coronavirus. This virus can cause mild disorders of the respiratory system, severe lung infections, and even death. COVID-19 can affect anyone, especially children. This research aims to explore children's experiences in preventing COVID-19. This study uses qualitative methods to explore the children's experiences. The participants in this study were ten children who were selected through the purposive sampling technique.. The results obtained are that there are five themes, namely, Perceived severity, Perceived susceptibility, Perceived Benefits, Perceived barriers, and Health Motivation. In this research, preventive behaviors carried out by children were to maintain distance, wear masks, wash their hands, and consume vitamins and nutritious foods. It is hoped that nurses can motivate so that children can carry out preventive behaviors not to become infected with COVID-19.
\end{abstract}

Keywords: COVID-19, preventive, children

\section{PENDAHULUAN}

Akhir tahun 2019, dunia digemparkan oleh merebaknya virus baru yang dikenal sebagai coronavirus jenis baru (SARS-CoV2). Virus tersebut menyebabkan penyakit yang disebut Coronavirus disease 2019 (COVID-19). Penyakit ini dimulai dari munculnya kasus pneumonia yang belum diketahui etiologinya di Wuhan, China. COVID-19 merupakan penyakit menular yang menyerang sistem pernapasan yang disebabkan oleh infeksi virus corona atau severe acute respiratory syndrome coronavirus 2 (SARS-CoV-2). Virus ini dapat menyebabkan gangguan ringan pada sistem pernapasan, infeksi paru-paru berat, hingga kematian (Fadli, 2020). Pada kasus infeksi pernapasan ringan, virus ini hanya akan menimbulkan gejala flu bagi penderitanya. Namun, pada kasus lain virus ini juga dapat menyebabkan infeksi pernapasan berat seperti infeksi paru-paru (pneumonia) (Ashikkali et al., 2020). 
Sejak virus COVID-19 pertama kali diumumkan pada Desember 2019, laju penyebaran penyakit cepat di seluruh dunia hingga WHO menetapkan situasi ini sebagai pandemi dan darurat kesehatan internasional. Jumlah kasus terinfeksi dan kematian juga masih mengalami peningkatan setiap hari (Ashikkali et al., 2020). Hal ini menuntut perubahan yang belum pernah terjadi sebelumnya pada masyarakat dalam cara mengatur diri secara sosial dan dalam rutinitas harian, tak terkecuali anak (de Figueiredo et al., 2021).

Banyak penelitian mengungkapkan bahwa komposisi usia pasien COVID-19 berdampak langsung pada tingkat kematian. Dibandingkan kelompok usia anak-anak dan kelompok usia yang lebih muda, penderita penyakit terbanyak adalah kelompok usia lanjut (kelompok usia 65 tahun ke atas). Dari sudut pandang kesehatan, anak-anak dan remaja kurang terpengaruh secara langsung daripada orang dewasa dan presentasi penyakit memiliki menunjukkan karakteristik yang berbeda. Meskipun demikian, COVID-19 berdampak parah pada anak-anak dan remaja. Implikasi tidak langsung dan hilir ini tidak boleh diabaikan (Ashikkali et al., 2020; Thaw et al., 2019).

Studi memperkirakan kurang dari $1 \%$ anak berusia dibawah 10 tahun terinfeksi COVID-19 dan 2,4\% diantaranya berusia kurang dari 18 tahun dengan tingkat kematian pada anak dibawah 10 tahun hampir sebesar 0. Studi COVID-19 pediatrik menyatakan sebanyak 2143 anak-anak dengan pemeriksaan laboratorium yang terkonfirmasi atau terduga COVID-19, sebagian besar pasien anak-anak $(94,1 \%)$ didiagnosis sebagai asimptomatik, atau dengan penyakit ringan atau sedang. Penelitian oleh Tim Epidemiologi Tanggap Darurat Pneumonia nCov Cina pada 72.314 responden ditemukan sekitar 2\% dari 44.672 kasus COVID-19 yang tekonfirmasi adalah anakanak berusia 0-19 tahun. Sebanyak 0,9\% dari jumlah tersebut adalah anak berusia dibawah 10 tahun dengan angka kematian 1 anak pada kelompok usia 10-19 tahun (Zhang, 2020).

Data lain didapatkan dari Italia yang melaporkan sebanyak $1,2 \%$ dari 22.512 kasus COVID-19 pada 18 Maret 2020 (Livingston \& Bucher, 2020) dan 5\% dari
4226 kasus di Amerika Serikat hingga 16 Maret 2020 adalah anak-anak (Zaveri, 2020). Sementara itu, data kasus COVID-19 pada anak di Indonesia menunjukkan angka yang tinggi jika dibandingkan dengan China, Italia, maupun Amerika Serikat. Ikatan Dokter Anak Indonesia (IDAI) (2020) menyatakan bahwa hingga 18 Mei 2020 diketahui jumlah Pasien Dalam Pengawasan (PDP) sebanyak 3.324 anak dengan angka kematian anak berstatus PDP sebanyak 129 anak, 584 anak terkonfirmasi COVID-19, dan 14 anak anak meninggal akibat COVID19.

Data temuan kasus tersebut membuktikan bahwa kurang tepat jika dikatakan kelompok usia anak tidak rentan terhadap COVID-19 atau hanya akan mengalami penyakit ringan saja. Meskipun pada umumnya anak yang tertular COVID19 tidak menunjukkan gejala, bukan berarti COVID-19 tidak berbahaya bagi anak. Beberapa kondisi pada anak dapat membuatnya rentan menjadi komplikasi berat. Data Pusat Pengendalian dan Pencegahan Penyakit Amerika (CDC) (2020) menunjukkan bahwa anak-anak dan remaja yang lebih tua lebih berisiko untuk mengembangkan komplikasi mematikan, termasuk sindrom inflamasi multisistem dan gagal napas.

Berkaitan dengan dampak klinis, data yang tersedia menunjukkan bahwa proporsi kasus parah dan kritis tampaknya berbanding terbalik dengan usia yang menunjukkan bahwa pada anak, khususnya bayi dan anak prasekolah bisa lebih rentan terhadap morbiditas terkait COVID-19. Kasus dapat berlanjut menjadi infeksi saluran napas bawah. Kasus tersebut juga dapat dengan cepat memburuk menjadi sindrom distres pernapasan akut (ARDS), syok septik, asidosis metabolik refrakter, dan disfungsi koagulasi. Anak dengan kasus COVID berat dilaporkan pertama di China dengan keluhan awal gejala pencernaan, gejala awal saluran napas tidak jelas dan tidak ada riwayat penyakit sebelumnya dan kemudian memburuk menjadi ARDS, syok septik, dan gagal ginjal akut dengan cepat (Cui et al., n.d.; Zhang, 2020).

Selain itu, data virologi baru-baru ini menunjukkan bahwa pada individu asimptomatik maupun oligosimptomatik 
berpotensi membawa partikel SARS-CoV-2 dalam sekresi nasofaring mereka sehingga sangat memungkinkan menyebabkan penularan dini ke kontak dekat (Hagmann, 2020). Anak-anak pada umumnya masih menunjukkan perlindungan yang kurang optimal terhadap COVID-19 misalnya dalam hal tidak menutupi mulut ketika batuk atau bersin, tidak memakai masker wajah, sering menyentuh wajah, dan memasukkan benda lain ke dalam mulut. Akibatnya anakanak dan bayi dapat memainkan peran penting dalam penularan SARS-CoV-2 di komunitas (Seyedi et al., 2020).

Berdasarkan situasi tersebut, maka penting bagi anak untuk selalu melindungi diri. Pencegahan merupakan suatu tindakan terbaik yang dapat dilakukan oleh anak untuk penularan COVID-19. Langkah-langkah pencegahan tersebut dapat dilakukan dengan tetap mematuhi protokol kesehatan seperti menggunakan masker ketika keluar rumah, menjaga jarak, mencuci tangan dengan sabun, sebisa mungkin menghindari kerumunan. Penting pula bagi anak untuk mencari dan memahami informasi terkait COVID-19 agar mereka mengerti apa yang seharusnya mereka lakukan untuk menghindari penularan. Apabila anak mulai merasa tidak enak badan, alangkah baiknya jika anak dapat segera menyampaikan ke orang tua atau orang dewasa lainnya. Anak dapat menyampaikan apa yang sedang dirasakannya misalnya badan terasa panas, sakit kepala, atau sakit tenggorokan (Fadli, 2020). Karena hal demikian akan sangat membantu deteksi dini tanda dan gejala apakah anak terpapar COVID-19 atau tidak, sehingga dapat mempercepat penanganannya.

Praktik penerapan perilaku sehat dalam pencegahan COVID-19 menjadi tidak mudah dilakukan oleh anak apabila mereka tidak terbiasa, pengetahuannya kurang, dan sedikitnya kesadaran untuk berperilaku sehat (Prihati et al., 2020). Anak dalam situasi ini harus mempunyai kesadaran untuk bersikap mematuhi protokol kesehatan. Studi untuk meningkatkan pemahaman tentang dampak epidemi dan pandemi seperti COVID-19 pada kesehatan dan perkembangan anak dapat membantu memandu strategi untuk mencegah kerusakan pertumbuhan anak dan mendorong perkembangan positif. Selain itu, dengan memahami dampak pandemi dan pentingnya melaksanakan protokol kesehatan dapat meningkatkan kesadaran anak untuk menjadikan perilaku yang terkait dengan pencegahan COVID-19 seperti membiasakan cuci tangan dengan menggunakan sabun, memakai masker setiap keluar rumah, dan lain sebagainya menjadi sebuah kebiasaan. Kesadaran anak terkait hal ini dapat menjadi strategi yang efektif dalam menekan persebaran COVID19 pada anak. Kesadaran anak dapat menjadi perisai bagi dirinya untuk meminimalkan risiko terpapar COVID-19. Tolak ukur kesadaran seseorang dapat dilihat dari sikap dan pengetahuannya. Semakin baik tingkat pengetahuan anak maka akan semakin baik tindakan yang diambil anak untuk mencegah COVID-19. Maka dari hal ini anak juga harus mau mencari tahu dan mau menerima informasi yang diperlukan dimasa pandemi COVID-19. Disini, perawat dapat berperan aktif dalam memfasilitasi dalam pembentukan kesadaran anak terkait dengan hal tersebut (Prihati et al., 2020).

Perawat merupakan bagian dari pemberi asuhan keperawatan anak dan orang tuanya. Perawat dapat berperan dalam berbagai aspek dalam memberikan pelayanan kesehatan dan bekerjasama dengan anggota tim lain, dengan keluarga terutama dalam membantu memecahkan masalah yang berkaitan dengan perawatan anak. Dalam memfasilitasi pencegahan penularan COVID-19, perawat mempunyai beberapa peran penting salah satunya sebagai pendidik. Secara langsung, dalam hal ini perawat memberikan penyuluhan atau pendidikan kesehatan pada anak maupun orang tua dan secara tidak langsung menolong anak dan orangtua untuk memahami situasi penyakit yang sedang dialami (Yuliastati, 2016). Kebutuhan anak terhadap pendidika kesehatan dapat mencakup pengertian dasar COVID-19, cara menularan, tanda gejala orang yang terinfeksi, serta hal-hal yang harus dilakukan untuk mencegah COVID-19. Pendidikan kesehatan tersebut, perawat dapat mengubah tiga domain yaitu pengetahuan, keterampilan, serta sikap anak dan orangtua dalam hal kesehatan terutama dalam pencegahan COVID-19 (Anantyo et al., 2020; Yuliastati, 2016). 
Selain itu, perawat anak juga mempunyai peran sebagai konselor. Kondisi pandemi yang terjadi saat ini selain dapat mempengaruhi kesehatan juga dapat mempengaruhi psikologis anak. Perawat dalam hal ini perawat memfasilitasi pemberian koseling keperawatan ketika anak sedang membutuhkan. Berbeda dengan pendidikan kesehatan, dalam konseling perawat akan mendengarkan segala keluhan, kecemasan, atau apapun yang dirasakan anak sehingga keduanya dapat bertukar pikiran dan pendapat mengenai situasi pandemi yang sedang dihadapi oleh anak dan mencarikan alternatif pemecahannya.

Tujuan penelitian ini adalah mempelajari perilaku pencegahan anak di Besuki Raya dalam menanggapi ancaman yang dirasakan dari pandemi COVID-19.

\section{METODE PENELITIAN}

Metode penelitian kualitatif dipilih sebagai pendekatan karena penelitian ini mencoba mengeksplorasi perilaku pencegahan anak dalam menghadapi pandemik COVID-19. Perilaku pencegahan anak dalam menghadapi pandemik COVID19 adalah pengalaman yang akan dieksplorasi menggunakan metode penelitian kualitatif melalui pendekatan fenomenologis. Eksplorasi mendalam akan digunakan dalam intervensi keperawatan berikutnya pada pasien anak. Penelitian ini dilakukan di karisidenan besuki yang mencakup Jember, Bodowoso, dan Banyuwangi. Penelitian ini dilakukan pada bulan September-November 2020. Teknik pengambilan sampel dalam penelitian ini menggunakan purposive sampling, yaitu teknik penentuan sampel data dengan memasukkan pertimbangan khusus yang ditentukan oleh peneliti.

Kriteria untuk peserta dalam penelitian ini adalah klien anak-anak pada usia sekolah (6-12 tahun), anak-anak yang bisa berbahasa Indonesia, dan keluarga yang menyetujui Persetujuan Informed. Partisipan dalam penelitian ini adalah 10 partisipan dengan wawancara mendalam dengan menggunakan lebar wawancara semi terstruktur. Pertanyaan berjumlah 5 item yaitu: 1. Apa yang adik ketahui tentang
COVID-19?; 2. Bagaimana pandangan adik tentang orang yang terkena COVID 19?; dan 3. Apa yang anda lakukan tidak terkena COVID-19?; dan 4. Apa yang adik takuti dalam pandemic COVID-19?. Jumlah peserta diambil karena data mencapai titik jenuh dengan jumlah peserta 10 anak.

Pengambilan data menggunakan perekam MP4 dan data dalam transkrip hasil wawancara. Menganalisis data dengan mengelompokkan sub-kategori dan Menganalisis data dengan mengelompokkan tema dan menentukan kategori dari setiap pernyataan klien anak. Penelitian ini telah melewati persetujuan etika No.41/UN25.1.14/KEPK/2020 di Fakultas Keperawatan Universitas Jember.

\section{HASIL DAN PEMBAHASAN}

Karakteristik responden yang pada penelitian berupa data jenis kelamin dari partisipan. Partisipan dalam penelitian ini berjumlah 10 anak usia sekolah yang terdiri dari 6 laki-laki (60\%) dan 4 perempuan (40\%) berlokasi di Jember, Bondowoso, dan Banyuwangi. Hasil wawancara kepada 10 partisipan anak usia sekolah di tiga kabupaten yaitu Jember, Bondowoso, dan Banyuwangi didapatkan hasil berupa beberapa tema dan kategori.

Tema pertama adalah ancaman yang dirasakan dengan dua kategori yaitu:

\section{Ancaman yang dirasakan}

\section{a. Virus COVID-19}

"Karena bisa terkena bersinnya orang tersebut, bisa karena kontaminasi dengan berjabat tangan."

"Seperti flu, batuk."

"Hampir sama tapi lebih mematikan."

"Kalau flu.. eh kalau COVID itu gejalanya lebih mematikan."

b. Aktivitas jika terkena COVID-19

"isolasi di rumah sakit karena agar tidak menular ke semua orang."

"menghindari orang-orang yang belum terkena COVID agar tidak menulari orang tersebut."

"tidak berada pada satu ruangan dengan keluarga yang terkena COVID, dan.. rajin mencuci tangan, tidak menggunakan peralatan yang sama dengan keluarga yang terkena COVID-19." 
Tema kedua adalah kerentanan yang dirasakan dengan satu kategori yaitu:

\section{Kerentanan yang dirasakan}

\section{a. Pandangan terhadap pasien COVID-19}

"orang yang terkena COVID19 bisa sembuh, bisa dengan cara istirahat yang cukup, makan-makanan yang bergizi, kemudian isolasi diri dari orang lain. Orang yang meninggal karena COVID19 itu biasanya karena penyakit lain yang sudah diderita sejak awal."

"Eem.. ya orang yang terkena COVID itu perlu mendapatkan dukungan dari orang sekitarnya."

Tema ketiga adalah manfaat yang dirasakan dengan dua kategori yaitu:

3. Manfaat yang dirasakan

a. Keuntungan penggunaan masker "Soalnya memakai masker itu bisa mencegah COVID-19... kita pada kemungkinan tertular COVID dari orang lain."

"Memakai masker tidak sepenuhnya melindungi dari virus korona, sebaiknya kita mengikuti anjuran pemerintah."

\section{b. Keuntungan konsumsi vitamin dan makanan bergizi}

"soalnya vitamin dan makanan bergizi itu dapat meningkatkan kesehatan kita."

"karena dapat meningkatkan daya tahan tubuh agar tdak terkena COVID19."

"pola hidup sehat, olahraga secara teratur, dan makan makanan bergizi."

Tema keempat adalah hambatan yang dirasakan dengan satu kategori yaitu:

\section{Hambatan yang dirasakan}

\section{a. Takut dengan pemberitaan COVID}

"Banyak berita Hoax COVID yan tidak benar sehingga saya takut dalam melakukan kegiatan"

"angka yang sakit tiap hari tambah banyak, jadi saya takut dan diam dirumah"

Tema lima adalah motivasi kesehatan dengan satu kategori yaitu

\section{Motivasi Kesehatan}

\section{a. Kegiatan untuk mencegah}

"Ya memakai masker tentunya jika keluar rumah, rajin cuci tangan menggunakan sabun, kalau keluar rumah membawa hand sanitizer, makan makanan yang bergizi."

"...ya cuci tangan"

"Memakai masker,"

"Eeem.. kalo mau makan cuci tangan,"

Perceiced severity atau keseriusan yang dirasakan merupakan penilaian subjektif terhadap tingkat keparahan masalah kesehatan dan potensi konsekuensinya. Seseorang akan membuat pertimbangan pada seberapa parah konsekuensi yang akan muncul apabila permasalahan ia membiarkan penyakitnya tanpa diberi penanganan dari petugas kesehatan. Berdasarkan teori Health Belief Model, individu akan menunjukkan perilaku pencegahan masalah atau mengurangi keparahan ketika mereka merasa masalah kesehatan yang dihadapi serius. (Husna, 2014). Keseriusan yang dirasakan tersebut meliputi keyakinan tentang penyakit itu sendiri seperti apakah penyakit tersebut dapat mengancam jiwa atau menyebabkan kecacatan, serta dampak yang lebih luas yang ditimbulkan pada pekerjaan dan peran sosial (Onoruoiza et al., 2015).

Penelitian ini menunjukkan sebagian besar anak merasa bahwa dampak dari pandemi yang dialami merupakan masalah yang serius. Anak memahami bahwa siapapun dapat terdampak pada bahaya penularan COVID-19, termasuk dirinya sendiri. Menurut mereka, infeksi COVID-19 tidak hanya membuat mereka mengalami gejala flu seperti biasa. Namun pada kasus berat bisa sampai menyebabkan kematian. Laporan klinis menunjukkan dampak infeksi yang lebih ringan pada anak-anak yang tekena COVID-19 dengan gejala yang dirasakan seperti pilek dengan demam, batuk, pilek, dan manifestasi pada gastrointestinal seperti muntah dan diare (Pavone et al., 2020).

Namun pada beberapa kondisi tertentu apabila anak mempunyai penyakit penyerta, anak dapat mengalami komplikasi berat seperti syok septik dan gejala sindrom gangguan pernapasan akut. Dampak yang ditimbulkan oleh COVID-19 tidak hanya pada fisik saja, tapi dapat berdampak pada 
psikologis anak. Sederhananya, fisik yang bermasalah juga akan mengarah pada psikologis (Lestari, 2020). Ketika anak terdiagnosa COVID-19, mereka akan menjalani perawatan, berada pada ruang isolasi yag membuat mereka terpisah dari orangtua, keluarga, dan teman-teman mereka. Hal tersebut tentu akan membuat anak merasa sendiri dan ketakutan sehingga dapat mempengaruhi psikologis anak serta menghambat proses penyembuhan anak. Masalah tersebut sama halnya apabila ada anggota keluarga anak yang terinfeksi. Umumnya, kebanyakan orang akan beranggapan bahwa pasien COVID-19 memerlukan perawatan yang maksimal dari petugas kesehatan, tapi yatanya keluarga terutama anak juga perlu mendapat perhatian. Kecemasan yang dirasakan anak ketika ada anggota keluarganya yang terkena COVID-19 dan harus terpisah untuk menjalani perawatan juga dapat menyebabkan masalah psikologis pada anak. Anak juga akan dibayang-bayangi ketakutan akan penularan virus dalam rumahnya.

Berdasarkan hal tersebut, anak merasa bahwa mereka harus benar-benar melindungi diri mereka agar terhindar dari penularan COVID-19. Tingkat keparahan penyakit yang dirasakan menyebabkan seseorang percaya bahwa konsekuensi yang ditimbulkan dari tingkat keparahan yang dirasakan merupakan ancaman bagi hidupnya. Sehingga seseorang akan mengambil tindakan untuk melakukan pengobatan dan mencegah penyakit. Dari uraian tersebut peneliti beropini bahwa persepsi terhadap perceived severity sangat diperlukan oleh anak untuk menghadapi kondisi pandemi pada saat ini. Tingkat perceived severity mempengaruhi anak dalam mengambil tindakan yang diperlukan untuk pencegahan infeksi COVID dan pengobatan apabila anak atau anggota keluarganya terdiagnosa COVID-19. Artinya, dalam penelitian ini anak merasa bahwa COVID-19 merupakan infeksi penyakit yang menancam bagi dirinya sehingga mereka perlu melakukan upaya untuk agar tidak terinfeksi COVID-19 (Attamimy, 2018).

Perceived susceptibility atau kerentanan yang dirasakan merupakan unsur selanjutnya yang dapat mempengaruhi persepsi individu untuk melakukan tindakan sesuai dengan perilaku kesehatan. Perilaku pencegahan COVID-19 ditinjau dari perceived susceptibility didasari oleh kemampuan anak dalam merasakan seberapa besar kemungkinan individu tersebut dapat tertular COVID-19 jika tidak mematuhi protokol kesehatan. Sehingga apabila anak merasa bahwa dirinya merupakan kelompok rentan yang juga rentan tertular COVID-19 maka mereka akan melakukan tindakan pencegahan untuk melindungi dirinya. Hasil penelitian ini menunjukkan bahwa anak merasa dirinya juga memiliki kemungkinan untuk tertular COVID-19. Hal ini terlihat dari bagaimana pandangan anak terhadap orang yang terkena COVID-19 dan beritaberita mengenai angka kasus COVID-19 yang terus meningkat. Mereka mengatakan bahwa infeksi COVID-19 merupakan hal yang nyata, apalagi ketika orang yang terinfeksi adalah orang disekitarnya. Kasus tersebut membuat anak dibayangi oleh ketakutan bagaimana kalau mereka juga tertular.

Namun terlepas dari ketakutan itu, anak juga berpendapat bahwa orang-orag yang terinfeksi COVID-19 perlu mendapatkan dukungan dari orang sekitar. Sehingga meskipun anak tahu bahwa COVID-19 menular, mereka tidak perlu menyudutkan dan memberikan stigma negatif pada orang tersebut. Tingginya jumlah kasus COVID-19 yang banyak diberitakan di media juga mempengaruhi ketakutan anak akan keberadaan virus tersebut disekitar mereka. Menurut mereka orang-orang, terutama dirinya sendiri harus lebih berperilaku sehat agar terhindar dari penularan COVID serta menimbulkan kasus baru yang dapat menambah jumlah kasus. Persepsi akan kerentanan sebenarnya mengacu pada penilaian subyektif dari risiko tergadap masalah kesehatan. Individu yang merasa dirinya tidak memiliki risiko rendah terhadap suatu penyakit mempunyai kemungkinan untuk melakukan tindakan yang kurang sehat, sedangkan individu yang merasa dirinya berisiko terhadap suatu penyakit akan lebih mungkin untuk berperilaku mengurangi risiko terserang penyakit (Onoruoiza et al., 2015).

Persepsi yang baik terhadap perceived susceptibility akan meningkatkan upaya 
individu dalam mencegah kekambuhan asma bronchial. Berdasarkan uraian hasil penelitian tersebut peneliti beropini bahwa dalam upaya pencegahan terhadap ancaman COVID-19 anak harus memiliki persepsi perceived susceptibility yang baik (Husna, 2014). Perceived susceptibily mempunyai pengaruh terhadap tindakan pencegahan yang dilakukan individu untuk mencegah penyakit. Sehingga apabila kerentanan yang dirasakan anak terhadap COVID-19 baik maka anak memiliki kemungkinan melakukan perilaku hidup sehat untuk mencegah penularan COVID-19, sebaliknya jika kerentanan yang diraskan kurang baik maka dapat menjadi penghambat dalam melakukan pencegahan.

Manfaat yang dirasakan (perceived benefits) merupakan persepsi individu terhadap nilai atau manfaat dari perilaku baru dalam mengurangi dampak dari ancaman penyakit yang diderita (Yuliana, 2020). Seseorang akan melakukan tindakan preventif yang direkomendasikan terkait kesehatannya bergantung pada manfaat yang dirasakan. Rendahnya persepsi individu terhadap perceived benefits secara signifikan bisa mempengaruhi motivasi individu dalam melakukan tindakan pencegahan. Dalam penelitian ini, anak merasa bahwa dirinya mempunyai risiko untuk tertular maupun menularkan COVID-19, dan mereka mampu melakukan suatu tindakan untuk mengatasi hal tersebut (Attamimy, 2018). Mereka akan bertindak asalkan mereka memperoleh banyak manfaat dari tindakan yang mereka lakukan. Anak memiliki persepsi bahwa dengan mematuhi protokol kesehatan seperti memakai masker, menjaga jarak, mencuci tangan, menghindari kerumunan, mengkonsumsi makanan bergizi dapat menghindarkan mereka dari penularan COVID-19. Persepsi yang baik terhadap manfaat dilakukannya pencegahan kekambuhan asma bronchial sehingga mempengaruhi responden dalam melakukan tindakan pencegahan.

Berdasarkan uraian ini, peneliti beropini bahwa persepsi terhadap manfaat yang diperoleh anak ketika melakukan tindakan pencegahan penularan COVID-19 mempengaruhi anak untuk terus menerapkan protokol kesehatan dalam kehidupan sehariharinya selama masa pandemi sebagai upaya pencegahan yang dapat mereka lakukan. Sebaliknya, apabila persepsi terhadap manfaat yang dirasakan rendah akan menjadi sesuatu yang dapat menghambat pengambilan tindakan pencegahan (Husna, 2014).

Tingginya persepsi terhadap rintangan yang dirasakan (perceived barriers) dalam tindakan pencegahan secara signifikan dapat berpengaruh terhadap rendahnya kemauan individu untuk melakukan upaya pencegahan. Hasil penelitian ini menunjukkan bahwa hal-hal yang menjadi perceived barriers anak dalam menghadapi COVID-19 adalah ketakutan mereka dan dukungan dari orang-orang disekitar anak. Sebagian besar anak memiliki ketakutan terhadap situasi pandemi COVID-19 ini. Mereka memiliki ketakutan apabila mereka tertular COVID-19, terlebih pada banyaknya kabar-kabar atau berita tentang kasus COVID-19 pada situasi ini. Anak-anak mengaku karena begitu takutnya, mereka lebih memilih tetap mematuhi protokol kesehatan meskipun ia masih melihat orangorang disekitarnya belum mematuhi protokol kesehatan.

Meskipun demikian, beberapa anak mangaku bahwa mereka tidak perlu begitu takut sebab ketakutan yang berlebih juga dapat membuat cemas dan imun mereka turun sehingga akan mudah terkena penyakit. Persepsi tentang perceived barries yang rendah dalam melakukan pencegahan kekambuhan asma bronchial, sehingga individu termotivasi untuk melakukan tindakan untuk mencegah kekambuhan asma bronchial. Berdasarkan uraian tersebut, peneliti menyimpulkan bahwa persepsi terhadap perceived barriers mempunyai pengaruh terhadap perilaku pencegahan penularan COVID-19 pada anak (Husna, 2014). Semakin tinggi persepsi perceived barriers anak maka kemungkinan anak untuk melakukan tindakan pencegahan COVID-19 akan semakin kecil. Sebaliknya, semakin rendah persepsi perceived barriers anak maka kemungkinan anak untuk melakukan tndakan pencegahan COVID-19 akan semakin besar.

Health motivation merupakan konstruk terkait dengan bagaimana motivasi individu untuk selalu hidup sehat. Health motivation diperlukan anak dalam berperilaku untuk 
mencegah penularan COVID-19. Mengingat kemampuan anak dalam mengatasi masalah masih berada dalam proses kematangan yang berbeda dibandingkan dengan orang dewasa, maka pembentukan health motivation anak untuk berperilaku mencegah penularan COVID-19 tidak lepas dari peran dari pihak-pihak tertentu, salah satunya peran dari perawat. Perawat mempunyai peran penting dalam membantu anak untuk berperilaku mencegah infeksi COVID-19. Sebagai edukator, perawat dapat secara langsung memberikan penyuluhan atau pendidikan kesehatan pada anak dan memberikan pemahaman terkait situasi penyakit yang sedang dialami.

Kebutuhan anak terhadap pendidikan kesehatan dapat mencakup pengertian dasar COVID-19, cara menularan, tanda gejala orang yang terinfeksi, serta hal-hal yang harus dilakukan untuk mencegah COVID19. Pendidikan kesehatan yang diberikan oleh perawat ke anak dapat mengubah pengetahuan, keterampilan, serta sikap anak dalam hal kesehatan terutama pencegahan COVID-19. Penyuluhan dan pendidikan kesehatan terkait Perilaku Hidup Bersih dan Sehat (PHBS) dapat merubah pengetahuan, sikap, dan praktik (Aspiah, 2020). Selain membantu anak dalam pemberian edukasi, perawat juga dapat membantu anak dalam menghadapi faktor-faktor yang mempengaruhi seperti ketersediaan fasilitas misalnya, pengadaan masker, pemberian tempat cuci tangan disetiap lokasi tertentu. Berdasarkan uraian tersebut, maka peneliti beropini bahwa perawat mempunyai peran yang penting dalam membantu anak dalam berperilaku untuk mencegah COVID-19. Maka dari itu, diperlukan kerjasama yang baik antara perawat, keluarga, serta masyarakat untuk lebih memperhatikan aturan-aturan di dilingkungan anak terkait pencegahan infeksi. Pemberian edukasi yang berkesinambungan juga diperlukan agar anak bisa mempertahankan health motivation untuk selalu mengambil tindakan ke arah pencegahan.

\section{KESIMPULAN DAN SARAN}

Kesimpulan yang diperoleh pada penelitian ini adalah ada lima tema yaitu perceived severity, perceived susceptibility, perceived benefit, perceived bariers, dan health motivation. Dalam penelitian ini, perilaku preventif yang dilakukan oleh anak adalah menjaga jarak, memakai masker, mencuci tangan, dan mengkonsumsi vitamin dan makanan bergizi. Saran yang diharapkan adalah perawat dapat memotivasi agar anak dapat melakukan perilaku preventif sesuai dengan aturan pemerintah agar tidak tertular COVID-19.

\section{REFERENSI}

Anantyo, D. T., Kusumaningrum, A. A., Rini, A. E., Radityo, A. N., Rahardjani, K. B., \& Sarosa, G. I. (2020). Coronavirus Disease 2019 (COVID19) Pada Anak (Studi Literatur). Medica Hospitalia: Journal of Clinical Medicine, 7(1A), 344-360. https://doi.org/10.36408/mhjcm.v7i1a. 479

Ashikkali, L., Carroll, W., \& Johnson, C. (2020). The indirect impact of COVID19 on child health. Paediatrics and Child Health (United Kingdom), 30(12), 430-437. https://doi.org/10.1016/j.paed.2020.09. 004

Aspiah, A., \& Mulyono, S. (2020). Peran Perawat Sekolah dalam Memberikan Edukasi Kesehatan Terkait Perilaku Hidup Bersih dan Sehat pada Anak Usia Sekolah: Tinjauan Literatur. Jurnal Penelitian Kesehatan "SUARA FORIKES" (Journal of Health Research "Forikes Voice"), 11(Khusus), 26. https://doi.org/10.33846/sf11nk204

Attamimy, H. B., \& Qomaruddin, M. B. (2018). Aplikasi Health Belief Model Pada Perilaku Pencegahan Demam Berdarah Dengue. Jurnal PROMKES, $5(2)$, 245. https://doi.org/10.20473/jpk.v5.i2.2017 .245-255

Cui, X., Zhang, T., Zheng, J., Zhang, J., Si, P., Xu, Y., \& Guo, W. (n.d.). Children with coronavirus disease. J Med Virol, 2020, 10100226023.

de Figueiredo, C. S., Sandre, P. C., Portugal, L. C. L., Mázala-de-Oliveira, T., da Silva Chagas, L., Raony, Í., Ferreira, E. S., Giestal-de-Araujo, E., dos Santos, 
A. A., \& Bomfim, P. O. S. (2021). COVID-19 pandemic impact on children and adolescents' mental health: Biological, environmental, and social factors. Progress in NeuroPsychopharmacology and Biological Psychiatry, 106, 220171. https://doi.org/10.1016/j.pnpbp.2020.1 10171

Fadli, A. (2020). Mengenal Covid-19 dan Cegah Penyebarannya Dengan "Peduli Lindungi ." In Jurnal Kesehatan (Issue April). Artikel Pengabdian Kepada Masyarakat. Jurusan Teknik Elektro.

Hagmann, S. H. F. (2020). COVID-19 in children: more than meets the eye. Travel Medicine and Infectious Disease, 34(xxxx).

Husna, C. (2014). Upaya Pencegahan Kekambuhan Asma Bronchial Ditinjau Dari Teori Health Belief Model Di Rsudza Banda Aceh. Idea Nursing Journal, 5(3), 75-89. https://doi.org/10.52199/inj.v3i3.1568

Livingston, E., \& Bucher, K. (2020). Coronavirus Disease 2019 (COVID19) in Italy. Jama, 323(14), 1335. https://doi.org/10.1001/jama.2020.434 4

Onoruoiza, S. I., Musa, A., Umar, B. D., \& Kunle, Y. S. (2015). Using Health Beliefs Model as an Intervention to Non Compliance with Hypertension Information among Hypertensive Patient. International Organization of Scientific Research Journal Of Humanities And Social Science, 20(9), 11-16. www.iosrjournals.org

Pavone, P., Ceccarelli, M., Taibi, R., Rocca, G. L. A., \& Nunnari, G. (2020). Outbreak of COVID-19 infection in children: Fear and serenity. European Review for Medical and Pharmacological Sciences, 24(8), 4572-4575.

https://doi.org/10.26355/eurrev_20200 4_21043

Prihati, D. R., Wirawati, M. K., \& Supriyanti, E. (2020). Analisis Pengetahuan Dan Perilaku Masyarakat Di Kelurahan Baru Kotawaringin Barat Tentang Covid 19. Malahayati Nursing Journal, 2(4), 780-790. https://doi.org/10.33024/manuju.v2i4.3
073

Rika Lestari 7-6-20. (n.d.). Gangguan pada Psikologis Anak saat Pandemi Covid19-Medcom.id.

https://www.medcom.id/rona/keluarga/ aNraA7EK-gangguan-pada-psikologisanak-saat-pandemi-covid-19

Seyedi, S. J., Shojaeian, R., Hiradfar, M., Mohammadipour, A., \& Alamdaran, S. A. (2020). Coronavirus disease 2019 (COVID-19) outbreak in pediatrics and the role of pediatricians: A systematic review. Iranian Journal of Pediatrics, 30(2), $\quad 1-4$. https://doi.org/10.5812/IJP.102784

Thaw, S., Santati, S., \& Pookboonmee, R. (2019). Factors Related to Preventive Behaviors Among Parent Caregivers of Children Under Five Years with Acute Respiratory Tract Infection in Myanmar. Makara Journal of Health Research, 23(1), 7-11. https://doi.org/10.7454/msk.v23i1.101 52

Yuliana, Y. (2020). Corona virus diseases (Covid-19): Sebuah tinjauan literatur. Wellness And Healthy Magazine, 2(1), 187-192.

https://doi.org/10.30604/well.9521202 0

Yuliastati, \& Arnis, A. (2016). Keperawatan Anak. In Kementerian Kesehatan Republik Indonesia. Kementerian Kesehatan Republik Indonesia.

Zaveri, A., \& Chouhan, P. (2020). Are child and youth population at lower risk of COVID-19 fatalities? Evidences from South-East Asian and European countries. Children and Youth Services Review, 119. https://doi.org/10.1016/j.childyouth.20 20.105360

Zhang, Y. (2020). The epidemiological characteristics of an outbreak of 2019 novel coronavirus diseases (COVID19) in China. Zhonghua Liu Xing Bing Xue $\mathrm{Za} \quad \mathrm{Zhi}=$ Zhonghua Liuxingbingxue Zazhi, 41(2), 145-151. https://doi.org/10.3760/cma.j.issn.0254 $-6450.2020 .02 .003$ 